\title{
Pemikiran Sa'ìd Ramadhān Al-Būthī Terhadap Isu-isu Feminisme (Kajian atas Penafsiran Sa'īd Ramadhān Al-Būthī terhadap Ayat-ayat Hijab, Kepemimpinan Perempuan, Hak Waris, dan Poligami)
}

\author{
M. Noor 'Ashry \\ Prodi Ilmu al-Quran dan Tafsir Fakultas Ushuluddin dan Pemikiran Islam, UIN Sunan \\ Kalijaga Yogyakarta \\ Email: muhammadnoor.mn838@gmail.com \\ Umi Wasilatul Firdausiyah \\ Prodi Ilmu al-Quran dan Tafsir Fakultas Ushuluddin dan Pemikiran Islam, UIN Sunan \\ Kalijaga Yogyakarta \\ Email: umiwasilah95@gmail.com
}

Naskah diterima: 24 November 2021, direvisi: 01 Januari 2022, disetujui: 06 Januari 2022

\begin{abstract}
This study aimed to elaborate the thoughts of Muhammad Sa'̄id Ramadhān al-Būthī regarding women and Islamic teachings that are considered discriminatory against women. As for several Islamic teachings discussed in this study, specifically hijab, women's leadership, inheritance rights, and polygamy. This research is library research and uses a qualitative approach. The theory used in this research is Hans George Gadamer's theory of effective hermeneutics. The results of this study are: 1) Hijab does not isolate women from all activities in life. But an extreme understanding of QS. an-Nur: 31 that caused disturbance to women which led to the decline of Islam; 2) Women's leadership is justified as long as they are not the head of state with certain conditions; 3) QS. an-Nisa: 11 (li adzdzakar mitsl hazzi al-untsayayn) is not a general rule in the distribution of inheritance. This rule only applies in certain conditions; 4) Polygamy is questioned by Western feminists because of the fundamental differences in perceptions between Islam and the West in seeing the essence and concept of marriage and adultery; 5) True equality is equality that does not contradict the nature that God has given to humans.
\end{abstract}

Keywords: Islam, Feminism Issues, Syekh Ramadhān al-Būthī.

\begin{abstract}
Abstrak
Penelitian ini bertujuan untuk mengelaborasi pemikiran Muhammad Sa'̄̄d Ramadhān alBūthī terkait perempuan dan ajaran Islam yang dianggap diskriminatif terhadap perempuan. Adapun sejumlah ajaran Islam yang dibahas dalam penelitian ini adalah hijab, kepemimpinan perempuan, hak waris, dan poligami. Penelitian ini merupakan penelitian kepustakaan dengan pendekatan kualitatif. Penelitian ini dilandasi teori hermeneutika efektual dari Hans George Gadamer. Penelitian ini berkesimpulan bahwa: 1) Hijab tidak mengisolasi perempuan dari segala aktivitas kehidupannya. Namun pemahaman yang ekstrem terhadap QS. an-Nur: 31 lah yang menimbulkan gangguan pada perempuan yang berujung pada kemunduran Islam; 2) Kepemimpinan perempuan dibenarkan selama tidak sebagai kepala negara dengan syarat-syarat tertentu; 3) QS. an-Nisa: 11 (li adz-dzakar mitsl hazzi al-untsayayn) bukanlah kaidah umum dalam pembagian harta warisan. Kaidah tersebut hanya berlaku pada kondisi tertentu saja; 4) Poligami dipermasalahkan oleh aktivis feminisme Barat dikarenakan adanya perbedaan persepsi yang mendasar antara Islam dan Barat dalam memandang esensi dan konsep pernikahan dan zina; 5) Kesetaraan yang benar adalah kesetaraan yang tidak menyelisihi kodrat yang diberikan Tuhan pada manusia.
\end{abstract}

Kata kunci: Islam, Isu-isu Feminisme, Ramadhān al-Būthī. 


\section{A. Pendahuluan}

Wacana tentang feminisme dalam Islam telah berkembang dalam beberapa dekade terakhir. Dimulai dengan propaganda-propaganda yang digaungkan oleh Barat tentang emansipasi wanita dan feminisme yang menawarkan kebebasan bagi perempuan. Propaganda-propaganda tersebut dimaksudkan untuk memojokkan Islam yang memarjinalkan kedudukan perempuan, dan bahkan telah merampas kebebasan perempuan. ${ }^{1}$ Seharusnya kehidupan berjalan sesuai dengan tujuan penciptaan manusia, baik laki-laki maupun perempuan untuk berperan dalam kepentingan masyarakat yang sama, walaupun pada dasarnya ada perbedaan fisik, psikis juga tempat peran yang berbeda. ${ }^{2}$ Dalam hal ini posisi perempuan perlu dipahami dalam perspektif Islam, sebagaimana dijelaskan Nasirudin Al-Ahsani dalam Kepemimpinan Perempuan dalam Masyarakat dalam Perspektif Sa ìd Ramaḍ̂̄n Al-Būthì: Telaah Hadis Misoginis, bahwa ada tiga golongan dalam Islam melihat posisi perempuan yakni berkenaan dengan golongan fundamentalis, liberal, dan progresif, yang secara garis besar ketiga golongan tersebut berhubungan erat dengan feminisme. ${ }^{3}$

Pembahasan mengenai feminisme bukan merupakan perbincangan baru, karena kemunculannya telah ada sejak awal abad 19 tepatnya pada 1808 yang dicetuskan dari salah seorang filsuf Prancis ${ }^{4}$ dan perkembangan pembahasan feminisme terus bergulir hingga abad ke-21 ini. Hal tersebut dapat dilihat dari kajian-kajian yang memunculkan pembahasan perempuan, seperti halnya Al-Wardah: Jurnal Kajian Perempuan, Gender dan Agama yang merupakan jurnal nasional. Pembahasan tentu berkaitan dengan problematika perempuan baik dalam kehidupan sosial-politik, pendidikan hingga dalam ranah agama dibahas di dalamnya, beberapa di antaranya seperti Peran dan Eksistensi Perempuan dalam Bidang Keluarga, Ekonomi, Pendidikan Menghadapi Era Indrustri karya Muh Amin Astuti dan Romi Adiansyah, juga Kesetaraan Gender dalam Perspektif Islam karya Adiyana Adam, tulisan Amin Bendar tentang Feminisme dan Gerakan Sosial dan banyak lagi dalam jurnal tersebut yang membahas berkenaan dengan hal-hal tersebut. Tidak hanya sampai di situ, tentunya banyak tulisan-tulisan lainnya pada jurnal-jurnal Nasional hingga internasional yang membahas hal tersebut. Akan tetapi pada kajian terkait perempuan dalam ranah kitab

\footnotetext{
${ }^{1}$ Muhammad Sa’̄̄d Ramadhān al-Būthī, Perempuan Antara Kezaliman Sistem Barat dan Keadilan Islam terj. Darsim dan Imam (Solo: Era Intermedia, 2002), hlm. 7.

${ }^{2}$ Muhammad Wahdini, "Politik Moderat: Studi Pemikiran Muhammad Sa'̄id Ramadhān al-Būthī," Jurnal Sosiologi Agama 14, no. 1 (1 Juni 2020): 62, https://doi.org/10.14421/jsa.2020.141-04.

${ }^{3}$ Nabila Ashriyanti dan Nasirudin Al Ahsani, "Kepemimpinan Perempuan dalam Masyarakat dalam Perspektif Sa '̄id Ramadhān Al-Būthī: Telaah Hadis Misoginis," Al-Hikmah 18, no. 1 (2019): hlm. 57.

4 Sahrani Adaruddin, "Feminisme Perspektif Islam," Al-Wardah: Jurnal Kajian Perempuan, Gender dan Agama 14, no. 2 (2020): hlm. 245, https://doi.org/10.46339.
} 
Al-Mar'ah Bayna Tughyān an-Nizhām Al-Gharbiy wa Lathā'if a-Tasyrī' ar-Rabbāniy karya Sa’̄̄d Ramadhān al-Būthī masih sedikit sekali yang mengkajinya.

Kitab tersebut secara eksklusif membahas mengenai perempuan dan problematikanya baik dalam Islam hingga pandangan Barat. Di samping itu al-Būthī merupakan salah seorang ulama kontemporer dan moderat yang dikenal kecerdasannya, dan dalam kitabnya tersebut juga dibahas mengenai problematika yang dituduhkan Barat terhadap Islam terkait kedudukan perempuan dalam agama. Dari penjelasan tersebut timbul pertanyaan, bagaimanakah al-Būthī menyikapi berbagai serangan dan tuduhan para feminis terhadap sebagian ajaran Islam yang dianggap diskriminatif terhadap perempuan? Dan seperti apa konsep kesetaraan dan perbedaan yang ditawarkan al-Būthī yang mendasari segala argumentasinya terkait ajaran-ajaran Islam yang dinilai diskriminatif? Pertanyaanpertanyaan tersebut muncul lantaran adanya kajian analisis yang dimunculkan oleh al-Būthī terkait perempuan dan kedudukannya dalam ajaran Islam, serta 'bias' dan 'diskriminatif' atas perempuan. Kiranya hal ini menarik untuk dianalisis kembali, mengingat kitab tersebut sangat membantu dan berkontribusi dalam pemahaman tentang posisi dan penempatan perempuan baik dalam Islam maupun pada pandangan non-Muslim.

\section{B. Metode Penelitian/Metode Kajian}

Suatu kajian tidak lengkap tanpa metodologi penelitian. Dalam kajian ini penulis menggunakan pendekatan kualitatif dengan jenis penelitiannya berupa Library Research dan teknik pengumpulan datanya berupa dokumentasi, lantaran dokumen dapat membantu untuk melihat hal-hal yang pernah dilakukan sebelumnya dan untuk memverifikasi keabsahan data, melakukan interpretasi dan penyimpulan kesimpulan. ${ }^{5}$ Sedangkan analisis datanya berupa deskriptif-analitis, sebagai jembatan untuk menjelaskan terkait pemikiran al-Būthī yang terdapat dalam kitabnya, yang dibantu dengan teori hermeneutika efektual dari Hans George Gadamer guna menganalisis makna dari teks yang tertuang dalam tulisan al-Būthī. Hermeneutika merupakan suatu metode atau cara untuk menerjemahkan simbol yang bentuknya berupa teks dalam proses pencarian maksud dan maknanya. ${ }^{6}$

Teori ini berupaya memahami maksud teks dengan menganalisis tiga aspek, yakni teks, pengarang dan pembaca. Gadamer berpendapat bahwa pemahaman terhadap makna

\footnotetext{
5 Aunu Rofiq Djaelani, "Teknik Pengumpulan Data dalam Penelitian Kualitatif," PAWIYATAN 20, no. 1 (2013): hlm. 88.

${ }^{6}$ Mudjia Baharjo, Dasar-dasar Hemeneutiks antara Intensionalisme \& Gadamerian (Yogyakarta: AR-RUZZ MEDIA, 2008), hlm. 29.
} 
teks memiliki keluasaan perspektif, sehingga tidak dapat dibatasai hanya dalam tulisan saja, melaikan penafsiran teksnya dapat dikembangkan berdasarkan kreativitas penafsirnya. Pemikiran ini mengidentifikasikan bahwa sebuah teks yang sudah dituangkan dalam tulisan dan dilempar keranah masyarakat maka seluruhnya menjadi hak pembaca dengan beragam pemahamannya dan keahliannya dalam mengartikan teks berdasarkan kata-kata yang tertulis dalam teks itu sendiri. ${ }^{7}$ Kemudian terkait keabsahan datanya penulis menggunakan triangulasi sumber, yakni menguji kredibilitas data yang dilakukan dengan memverifikasi kebenaran data yang telah diperoleh melalui beberapa sumber, ${ }^{8}$ pemilihan keabsahan data ini penulis pilih lantaran penelitian dalam penulisan ini merupakan jenis penelitian kepustakaan. Penjelasan lebih lengkapnya terdapat dalam subbab penjelasan berikut.

\section{Hasil dan Pembahasan}

\section{Posisi Perempuan dari Masa Klasik Hingga Kontemporer}

Perlakuan terhadap perempuan di berbagai tempat dan masa sangatlah beragam. Adakalanya, perempuan dihormati dan dimuliakan. Adakalanya pula dihinakan sehinahinanya dan diperlakukan layaknya barang komoditas yang bisa diperjualbelikan bahkan diwariskan. Hal ini terlihat dari fakta-fakta sejarah peradaban masa silam khususnya peradaban-peradaban praislam. Sebagai contoh pada masa kejayaan Yunani Kuno, para perempuan mengalami hal-hal yang mengerikan, tidak peduli apakah mereka dari kalangan elit bangsawan, maupun dari kalangan rakyat jelata, posisi mereka sama tidak punya hak untuk mengatur diri dan kehidupan mereka sendiri. Mereka yang dari kalangan elit dikekang di istana-istana mereka dengan sederet peraturan dan kewajiban yang harus mereka patuhi. Sedangkan mereka yang berasal dari kalangan jelata harus menerima nasib yang tragis, yakni menjadi barang komoditas yang diperjual-belikan. ${ }^{9}$

Selain itu, kaum perempuan juga tidak memiliki hak dalam memilih dan haknya juga tidak diakui, serta dan persetujuannya terhadap suatu hal dipandang tidak penting. Mereka sepenuhnya berada dalam kuasa laki-laki. Dalam hal ini adalah ayahnya, saudara laki-lakinya, suaminya, bahkan paman-pamannya. Mereka hanya dituntut untuk selalu tunduk dan patuh tanpa perlawanan. Magdalena dalam artikelnya mengklasifikasi perempuan pada masa Yunani Kuno menjadi 3 macam: 1) Mereka yang menjadi pelacur

\footnotetext{
${ }^{7}$ Baharjo, Dasar-Dasar Hemeneutiks Antara Intensionalisme \& Gadamerian, hlm. 90-91.

${ }^{8}$ Sugiyono, Metode Penelitian Kuantitatif, Kualitatif dan R\&D (Bandung: Alfabeta, 2016).

${ }^{9}$ M. Quraish Shihab, Wawasan Al-Qur'an: Tafsir Maudhu'i atas Pelbagai Persoalan Umat (Bandung: Mizan, 1999), hlm. 296.
} 
dan bertugas hanya untuk menjadi pemuas nafsu para lelaki; 2) Mereka yang menjadi selir-selir dan bertugas untuk merawat tubuh dan kesehatan tuannya; 3) Mereka yang menjadi isteri dan bertugas untuk merawat dan mendidik anak-anak mereka seperti baby sitter jika diasosiasikan pada masa kini. ${ }^{10}$ Kejadian ini juga tidak jauh beda pada masa masa kejayaan Romawi, perempuan masih tidak memiliki hak-hak individual dan kebebasan seperti halnya pada masa Yunani Kuno. Dan dapat dikatakan bahwa pernikahan pada masa Romawi sama halnya dengan perpindahan hak-hak atas seorang perempuan dari sang ayah kepada sang suami, dengan pengertian bahwa suami memiliki otoritas seperti sang ayah dalam mengatur dan menetapkan hukum untuk perempuan. Malangnya, karena hak-hak kepemilikan mereka tidak diakui, segala hal yang dimiliki oleh perempuan baik itu harta warisan maupun hasil keringatnya sendiri, menjadi hak milik keluarganya yang laki-laki. ${ }^{11}$

Hal yang sama juga terjadi pada peradaban Cina sebelum era Konfusianisme. Para perempuan sangat dihormati, namun setelah pengaruh ajaran Konfusianisme muncul dan mengakar kuat, sehingga perlakuan terhadap perempuan pun berubah. ${ }^{12}$ Ajaran Konfusianisme sendiri mengakar kuat di wilayah Asia Timur yang mencakup Cina, Jepang, dan Korea. Dalam ajaran Konfusianisme, kaum laki-laki ditempatkan pada kedudukan yang tinggi. Dengan demikian dapat dikatakan bahwa Konfusianisme sangat mendorong sistem patriarki Para laki-laki dipandang mempunyai tugas yang sangat mulia berupa melakukan upacara penghormatan pada leluhurnya. Upacara tersebut tidak dapat digantikan oleh seorang perempuan. Selain itu, anak laki-laki juga diperlukan untuk meneruskan garis keturunan untuk menjaga dan melestarikan kehormatan dan harta keluarga. Dengan demikian, tidak heran jika anak laki-laki lebih diutamakan dan diinginkan dibandingkan anak perempuan. Berbeda halnya dengan nasib perempuan. Menurut kepercayaan Konfusianisme, perempuan hanyalah makhluk lemah yang tidak berdaya. Peran perempuan hanyalah untuk melahirkan anak, dan mereka sangat dituntut

${ }^{10}$ R. Magdalena, "Kedudukan Perempuan Dalam Perjalanan Sejarah (Studi Tentang Kedudukan Perempuan Dalam Masyarakat Islam)," Harakat An-Nisa: Jurnal Studi Gender Dan Anak II, no. 1 (2017): hlm. 16, http://e-journal.lp2m.uinjambi.ac.id/ojp/index.php/an-Nisa/article/download/116/52/.

${ }^{11}$ Shihab, Wawasan Al-Qur'an, 296-97; Magdalena, "Kedudukan Perempuan Dalam Perjalanan Sejarah," hlm. 17.

${ }^{12}$ Hendri Hermawan Adinugraha, Asep Suraya Maulana, dan Mila Sartika, "Kewenangan dan Kedudukan Perempuan dalam Perspektif Gender: Suatu Analisis Tinjauan Historis," Marwah: Jurnal Perempuan, Agama dan Jender 17, no. 1 (2018): hlm. 45. 
untuk melahirkan anak laki-laki, sehingga mereka akan dianggap tidak berbakti jika tidak dapat memberikan anak laki-laki. ${ }^{13}$

Dalam ajaran Konfusianisme sendiri dikenal ajaran etis yang bernama "Tiga Ketaatan" dan "Tujuh Kejahatan”. Tiga ketaatan berarti para perempuan harus menaati tiga orang laki-laki dalam hidupnya yakni, 1) Ayahnya tatkala ia masih menjadi seorang anak; 2) Suaminya ketika ia sudah bersuami; 3) Anak laki-lakinya di saat suaminya telah meninggal dunia. Sedangkan tujuh kejahatan ialah sifat-sifat buruk yang menjadi tolok ukur dan alasan yang sah untuk menceraikan seorang perempuan. Adapun ketujuh kejahatan tersebut antara lain: 1) Tidak taat pada orang tua suami; 2) Gagal melahirkan anak laki-laki; 3) Berzina; 4) Cemburu; 5) Tertular penyakit berbahaya; 6) Bergosip; dan 7) Mencuri. $^{14}$

Beralih kepada kepercayaan agama Samawi praislam, Yahudi dan Kristen. Menurut Quraish Shihab, dalam ajaran Yahudi derajat seorang perempuan tidak ubahnya seorang pembantu. Para perempuan dalam Yahudi dianggap sebagai aktor utama penyebab terusirnya Adam AS. dari surga, sehingga para perempuan dipandang sebagai pembawa laknat dari Tuhan. Sama seperti sebelumnya, para perempuan dalam ajaran Yahudi juga boleh dijual oleh sang ayah dengan catatan perempuan tersebut tidak memiliki saudara laki-laki. Sedangkan dalam ajaran Kristen, para perempuan dianggap sebagai senjata Iblis yang akan menyesatkan para laki-laki. Selain itu, para perempuan juga pernah diragukan eksistensinya sebagai manusia dan mereka dianggap tidak memiliki ruh yang suci layaknya lelaki. Pada akhirnya, para perempuan dalam ajaran Kristen dianggap sebagai manusia yang tugasnya hanyalah untuk melayani laki-laki semata. $^{15}$

Sedangkan dalam peradaban Arab praislam, para perempuan juga memiliki nasib yang memilukan. Pada era yang disebut era Jahiliyyah ini para perempuan mendapatkan perlakuan yang tidak selayaknya dan menyedihkan. Bayi-bayi perempuan yang baru lahir biasanya dikubur hidup-hidup, dan ada sebagian yang dibiarkan hidup yang dirawat ala kadarnya, tanpa memberikan kasih sayang sebagaimana kasih sayang yang berlimpah yang diberikan kepada anak laki-laki. Perlakuan ini menurut Fatimah Umar Nasif -dalam

13 Muhammad Amin, "Feminisme Pada Modernisasi Di Jepang Nihon De No Kindaika Ni Taisuru Feminizumu" (Skripsi, Medan, Universitas Sumatera Utara, 2018), hlm. 19-20.

${ }^{14}$ Dwi Amanda Putri, "Peran Perempuan Dalam Keluarga Korea Pada Masa Dinasti Joseon (1392 - 1910) Berdasarkan Ajaran Konfusianisme" (diploma, Universitas Nasional, 2019), hlm. 20-21, http://repository.unas.ac.id/1806/.

${ }^{15}$ Shihab, Wawasan Al-Qur'an,... hlm. 297. 
bukunya Menggugat Sejarah Perempuan: Mewujudkan idealisme gender sesuai tuntunan Islam-didasari anggapan bahwa anak perempuan itu hanya akan mendatangkan kehinaan dan malapetaka. Selain itu, anak perempuan juga memiliki fisik yang lemah dan tidak bisa berperang sehingga hanya akan menjadi beban keluarga saja. ${ }^{16}$ Perempuan pada masa Jahiliyyah juga tidak memiliki hak waris terhadap harta warisan, bahkan diri mereka sendiri menjadi harta warisan yang diwarisi oleh anak laki-laki atau saudara laki-laki suaminya. ${ }^{17}$

Kemudian Islam hadir merubah kebiasaan Jahiliyyah yang mengesampingkan bahkan hanya memberikan sedikit ruang gerak juga kedudukan terhadap perempuan dan pada masa praislam juga muncul rasa malu juga hina terhadap diri mereka sendiri sebagai seorang perempuan. Dengan hadirnya perempuan dijanjikan akan memiliki hak-hak yang sama, akan tetapi setelah kemuduran Islam terjadi kekuasaan Islampun menurun dan lahirlah sistem kapitalis dan sosialis dalam kehidupan manusia. Dari hal tersebut muncullah sekat-sekat pembeda antara kewajiban dan posisi perempuan. Hal ini juga didorongan oleh pemikiran Barat yang mengikis pemikiran semula terhadap keberadaan perempuan, walaupun keberadaan perempuan telah mendapat kebaikan tidak seperti pada masa Jahiliyyah. ${ }^{18}$ Adanya pergeseran pemikiran ini pula mendorong golongan tertentu untuk mengusung kesetaraan antara laki-laki dan perempuan.

Penjelasan terkait kesetaraan kemudian melahirkan penjelasan berkenaan dengan feminisme, kesetaraan gender dan emansipasi, di mana feminisme dan jender merupakan bentuk dari suatu emansipasi dari Barat yang tidak lain pembahasannya merupakan perempuan. Istilah ini tepatnya feminisme, lahir pada abad ke-19 atau sekitar 1890-an yang diusung oleh Charles Fourier yang berkebangsaan Perancis terkait konsep kesetaraan dan beberapa dekade berikutnya muncullah kesetaraan gender yang digaungkan sebagai paradigma penyetaraan antar perempuan dengan laki-laki. ${ }^{19}$ Dengan salah satu dari tipologi feminis yakni berupa keberagamaan perspektif perempuan, yang berdampak pada keragaman perannya pada ruang publik, dan tentunya tidak terlepas dari

\footnotetext{
${ }^{16}$ Adinugraha, "Kewenangan Dan Kedudukan Perempuan,... hlm. 48.

${ }^{17}$ Elya Munfarida, "Perempuan dalam Tafsir Fatima Mernisi," Maghza 1, no. 2 (2016): hlm. 26.

18 Tri Handayani, "Reafirmasi Posisi Perempuan Mengulas Pandangan Lama," Jurnal Al-Dirayah 4, no. 1 (2018): hlm. 42-43.

19 Sugiri Permana, "Kesetaraan Gender Dalam Ijtihad Hukum Waris Di Indonesia," Asy-Syari'ah 20, no. 2 (2018): hlm. 118, https://doi.org/10.15575/as.v20i2.3210.
} 
tugasnya sebagai istri juga ibu bagi anak-anaknya, yang tidak lain merupakan peran internal keluarga. ${ }^{20}$

Sejatinya terkait feminsme juga emansipasi perempuan selalu menjadi wacana dalam kehidupan sejak masa pra-Islam, dan kemunculan feminis ini merupakan bagian dari kemajuan atas perempuan yang di anggap oleh para pendukung teori dan gerakan feminis. Kejadian ini terjadi sebelum adanya masyarakat urban. Kemunculan masyarakat urban menjadikan perempuan mengalami dampak penempatan posisi yang terpimbin dan dibelakang lantaran pada saat itu perempuan menjadi rebutan suku-suku, bagi perempuan yang memiliki sensitas tinggi dalam seksual dan reproduksi.

Secara tidak langsung hal tersebut menggambarkan bahwa perempuan memiliki posisi yang begitu dinamik mengikuti alur kehidupan, hingga terjalin komunikasi yang baik antarlelaki dan perempuan di seluruh lapisan masyarakat. Akan tetapi, pengaruh globalisasi informasi mengakibatkan perubahan fundamental terhadap gerakan feminis, sehingga harus selektif terhadap gagasan kaum feminis. ${ }^{21}$

\section{Sekilas Biografi Sa'īd Ramadhān al-Būthī}

Nama lengkapnya Muhammad Sa’īd Ramadhān ibn Mullā Ramadhān ibn Umar al-Būthī, dilahirkan pada 1929 M di sebuah desa bernama Jilika yang terletak di pulau Ibn 'Umar yang lebih masyhur dikenal sebagai pulau Būthān yang terletak di tepi Sungai Tigris di titik pertemuan antara perbatasan Suriah, Irak, dan Turki. Al-Būthī tumbuh dalam keluarga berketurunan Kurdi yang cerdas lagi religius dan saat usianya mencapai empat tahun, bersama ayahnya yakni Mullā Ramadhān al-Būthī juga keluarganya yang lain hijrah ke Damaskus pada 1933 untuk menghindari fitnah dan penganiayaan yang dilakukan oleh Kemal Ataturk terhadap umat Islam pasca jatuhnya kekhilafahan Turki Utsmani (Ottoman Empire). Beberapa tahun kemudian ibunya wafat yakni saat umurnya 13 tahun dan ayahnya menikah lagi dengan seorang wanita berkebangsaan Turki sehingga beliau relatif akrab dengan bahasa Turki selain bahasa Kurdi dan Arab yang merupakan bahasa ibunya. ${ }^{22}$

${ }^{20}$ Zahra Zaini Arif, "Peran Ganda Perempuan dalam Keluarga Pespektif Feminis Muslim Indonesia," Indonesian Journal of Islamic Law 1, no. 2 (2019): 97.

${ }^{21}$ Zainal Abidin, "Kesetaraan Gender dan Emansipasi Perempuan dalam Pendidikan Islam," Tarbawiyah Jurnal Ilmiah Pendidikan 12, no. 01 (2017): 1-16.

${ }^{22}$ Muhammad Mufid, Belajar dari: Tiga Ulama Syam Fenomenal dan Inspiratif (Jakarta: PT Elex Media Komputindo, 2015), hlm. 35-36. 
Semasa kecilnya, al-Būthī sangat terinspirasi oleh ayahnya sebagai salah satu gurunya dan merupakan salah satu Syekh terkemuka di bidang tasawuf dan ahli tharīqah an-Naqsyabandiyah yang mengajarkannya prinsip-prinsip akidah, ringkasan sìrah nabawī, dan ilmu-ilmu ālat yakni nahwu dan sharaf. Kecerdasan al-Būthī, sudah tampak sedari kecilnya sebagaimana kemampuannya dalam menghafal bait-bait alfiyah ibn Mālik yang berjumlah kurang lebih 1002 bait dalam waktu kurang dari setahun, juga menghafal Nazhm Ghāyah wa at-Taqrīb karya al- 'Imrithĭ. ${ }^{23}$ Dia pernah berkeinginan menghafalkan Al-Qur'an, namun niat ini tidak direstui ayahnya dengan alasan khawatir akan dosa yang akan menimpa beliau jika suatu saat melupakan hafalan tersebut. Kemudian atas nasihat ayahnya, al-Būthī mengiyakannya dan senantiasa mengkhatamkan bacaan Al-Qur'an setiap tiga hari sekali khatam ${ }^{24}$ juga konsisten mempelajari tafsir Al-Qur'an dari ayahnya dalam setiap harinya lima hingga enam ayat per hari. ${ }^{25}$

Sekolah dasar (ibtidā' $\grave{\imath}$ ) ditempuh di daerah Sarouja, salah satu distrik lama di Damaskus, yang khusus untuk mempelajari agama Islam, prinsip-prinsip bahasa Arab dan Matematika. Kemudian setalah selesai ayahnya mengirimnya belajar di Ma'had at-Taujīh al-Islāmī, dalam naungan Syekh Hasan Habanakah al-Maydānī, salah satu ulama Besar di Suriah dan pakar dalam bidang tafsir. Dari didikan Syekh Hasan Habannakah alMaydānī menjadikan al-Būthī seorang Ulama yang bijak dalam bersikap, terutama dalam hal menyikapi pemerintah. ${ }^{26}$ Dan seminggu sekali tepat hari selasa pulang ke rumahnya untuk memperdalam ilmu nahwu dan balāghah, hingga berhasil menghafalkan kitab 'Uqūd al-Jumān karya as-Suyūthī di bawah bimbingan ayahnya. Selama masa hidupnya, al-Būthī menikah sebanyak tiga kali dan dikaruniai tujuh orang anak dari istri pertama dan istri ketiga, sedangkan dari istri pertama dikaruniai tiga anak laki-laki dan satu perempuan. Sedang dari istri kedua beliau tidak dikaruniai keturunan, karena wafat setelah kurang dari 3 tahun usia perkawinan mereka. ${ }^{27}$

Setelah lulus dari pendidikan menengah pada 1953, al-Būthī kemudian melanjutkan studinya di Universitas al-Azhar, Kairo, dan berhasil menyelesaikan pendidikan strata satunya (S-1) di Fakultas Syari'ah, Universitas al-Azhar pada 1955. Dan

\footnotetext{
${ }^{23}$ Lihat محمد سعيد رمضان البوطي. Lihat juga "Said Ramadhān Al-Būthī, Ulama yang Menjadi Musuh Gerakan Oposisi” di https://islami.co/said-ramadhan-al-buthi-ulama-yang-menjadi-musuh-gerakan-oposisi/. Diakses pada tanggal 19 April 2020.

${ }^{24}$ Mufid, Belajar dari : Tiga Ulama Syam Fenomenal dan Inspiratif, 38.

${ }^{25}$ Lihat محد سعيد رمضان البوطي. Lihat juga “Mengenang Syaikh Muhammad Sa’̄̄d Ramadhān Al-Būth̄̄” dalam https://liputanislam.com/kajian-islam/mengenang-syaikh-muhammad-said-ramadhan-al-buthy/. Diakses pada tanggal 19 April 2020.

${ }^{26}$ Lihat "Sa'̄̄d Ramadhān al-Būthī, Ulama yang Menjadi Musuh Gerakan Oposisi”.

${ }^{27}$ Mufid, Belajar dari : Tiga Ulama Syam Fenomenal dan Inspiratif, hlm. 38-40.
} 
pada 1956 berhasil meraih diploma pendidikannya (setingkat S-2) di bidang Bahasa Arab dalam waktu yang sangat singkat. ${ }^{28}$ Kemudian pada 1965, meraih gelar doktoralnya di bidang fiqh dan ushūl fiqh dari Universitas al-Azhar dengan disertasi berjudul Dhawâbith Al-Mashlahah fi Asy-Syarî'ah Al-Islâmiyyah dengan predikat Summa Cumlaude serta direkomendasikan untuk diterbitkan dengan biaya universitas dan direkomendasikan untuk dipublikasikan di universitas lainnya. ${ }^{29}$

Karirnya berlanjut menjadi guru agama di sekolah menengah tingkat pertama dan kemudian di Dār al-Mu'allimīn ìbtidā'iyyah di daerah Hims. Al-Būthī juga sempat diangkat menjadi asisten dosen di Fakultas Syari'ah Universitas Damaskus atas rekomendasi Syekh Mushtafa as-Sibā'ī pada 1960 dan diangkat menjadi dosen tetap mata kuliah hukum perbandingan (al-Fiqh al-Islāmī al-Muqārin) dan studi agama (al- 'Aqā'id wa al-Adyān) di Universitas Damaskus, setelah menyelesaikan gelar doktoralnya.

Pada 1975 diangkat menjadi Guru Besar di bidang kajian fikih lintas mazhab (alFiqh al-Muqāran). Kemudian pada 1977 al-Būthī diangkat menjadi Dekan Fakultas Syari'ah, juga menjabat sebagai Direktur Kajian Teologi dan Agama di Universitas Damaskus sejak tahun 2002 hingga menjelang wafatnya. ${ }^{30}$ Pada tanggal 21 Maret 2013 atau malam Jum'at, 9 Jumadil Awal 1434 H al-Būthī wafat di Masjid al-Imān Damaskus, dalam peristiwa tragis bom bunuh diri yang dilakukan oleh kelompok ekstrem Suriah pendukung pihak oposisi. Peristiwa ini terjadi ketika beliau sedang menyampaikan pengajian tafsir mingguan di masjid tersebut. Al-Būthī dimakamkan bersebelahan dengan makam Raja Shalah ad-Dīn al-Ayyūbī di bawah benteng Damaskus. ${ }^{31}$

\section{Perempuan dan Isu-isu Feminisme}

Dapat dikatakan, banyak ajaran Islam yang diklaim telah mendiskreditkan kedudukan perempuan. Di antara ajaran tersebut antara lain adalah persoalan hijab, kepemimpinan perempuan, perbedaan hak waris, poligami dan berbagai ajaran lainnya yang dianggap telah turut ambil andil dalam memarjinalkan posisi perempuan dalam Islam. Namun, oleh al-Būthī klaim-klaim tersebut harus diluruskan. Berikut penulis

\footnotetext{
${ }^{28}$ Mufid, 40.

${ }^{29}$ Abdul Mukit, "Pendidikan Akidah: Telaah Pemikiran Muhammad Sa'īd Ramadhān al-Būthī," Tawazun: Jurnal Pendidikan Islam 8, no. 1 (30 Januari 2015): hlm. 6, https://doi.org/10.32832/tawazun.v8i1.1130; Mufid, Belajar dari : Tiga Ulama Syam Fenomenal dan Inspiratif, hlm. 41.

${ }^{30}$ Mufid, Belajar dari: Tiga Ulama Syam Fenomenal dan Inspiratif, hlm. 54; Mukit, "Pendidikan Akidah: Telaah Pemikiran Muhammad Sa'īd Ramadhān al- Būthī," 6.

${ }^{31}$ Mufid, Belajar dari : Tiga Ulama Syam Fenomenal dan Inspiratif, hlm. 86-87.
} 
paparkan pendapat al-Būthī mengenai empat persoalan di atas dalam beberapa sub bahasan antara lain:

a. Hijab

Terdapat setidaknya dua ayat dalam Al-Qur'an yang mengatur persoalan terkait kewajiban mengenakan hijab yakni QS. An-Nur: 31 dan QS. Al-Ahzāb: 59. Menurut asSuyūthi, QS. An-Nur: 31 diturunkan berkenaan dengan Asma' bint Murtsid. Dia memiliki kebun kurma yang seringkali dikunjungi oleh para perempuan, namun pada suatu waktu dia melihat para perempuan yang mengunjungi kebun kurma miliknya tidak mengenakan kain panjang sehingga terlihatlah gelang-gelang yang ada di kaki-kaki mereka, dan terlihat pula dada dan sanggul-sanggul mereka. Melihat pemandangan tersebut, Asma' pun berkata "Alangkah buruknya pemandangan ini”. Kemudian QS. An-Nur: 31 pun turun untuk memerintahkan perempuan mukmin untuk menutup aurat mereka. ${ }^{32}$

Sedangkan QS. Al-Ahzāb: 59 diturunkan berkenaan dengan peristiwa diganggunya isteri-isteri Rasulullah saw oleh orang-orang munafik pada malam hari ketika akan buang air. Peristiwa itu kemudian dilaporkan kepada Rasulullah saw dan orang-orang munafik tersebut ditegur oleh Rasulullah saw. Namun, mereka berdalih bahwa mereka hanya mengganggu hamba sahaya semata. QS. Al-Ahzāb: 59 pun turun sebagai perintah untuk mengenakan pakaian tertutup agar berbeda dari para hamba sahaya. ${ }^{33}$

Pada dua ayat di atas terdapat dua kata yang mewakili hijab, yakni khumur bentuk plural dari kata khimār dan jalābīb bentuk plural dari kata jilbāb. Al-Marāghī memaknai khimār sebagai kain yang menutupi kepala wanita (kerudung). ${ }^{34}$ Khimār ini diulurkan ke dada perempuan agar tidak nampak bagian leher dan dadanya. ${ }^{35}$ Kata jilbāb menurut alAshfahān̄̄ berarti gamis dan khimar. ${ }^{36}$ Serupa dengannya, Al-Marāghī memaknai aljalābīb (jilbāb) sebagai baju kurung yang meliputi seluruh tubuh wanita, lebih dari sekedar baju biasa dan khimār. ${ }^{37}$

Makna hijab sendiri sebenarnya adalah menghalangi untuk sampai. ${ }^{38}$ Ia berasal dari kata hajaba yang berarti menutupi, menghalangi, dan menyekat (satara). ${ }^{39}$ Menurut

${ }^{32}$ Jalāl ad-Dīn as-Suyūthī, Lubāb an-Nuqūl fì Asbāb an-Nuzūl (Beirut: Mu`assasah al-Kutub aś-Ṡaqāfiyyah, 2002), 187.

${ }^{33}$ as-Suyūthī, Lubāb an-Nuqūl fì Asbāb an-Nuzūl, 214.

${ }^{34}$ Ahmad Mushthafa Al-Marāghī, Tafsìr Al-Marāghī, vol. 18 (Mesir: Mushthafā al-Bābī al-Halbī, 1946), 97.

${ }^{35}$ Muhammad 'Alī ash-Shābūn̄i, Shafwat at-Tafāsìr , vol. 2 (Lebanon: Dār al-Fikr, 2001), 307.

${ }^{36}$ Ar-Raghīb Al-Așfahānī, Al-Mufradāt fì Gharīb al-Qur'ān, vol. 1 (t.t.: Maktabah Nizar Mushthafa al-Baz, t.th), 124 .

${ }^{37}$ Ahmad Mushthafa Al-Marāghī, Tafsīr Al-Marāghī, vol. 22 (Mesir: Mushthafā al-Bābī al-Halbī, 1946), 36.

${ }^{38}$ Al-Așfahānī, Al-Mufradāt fì Gharīb al-Qur'ān, 1:141.

${ }^{39}$ R Riyani, "Makna Hijab dalam Al-Qur'an: Studi Tematik Ayat-ayat Hijab" (Skripsi, Semarang, UIN Walisongo, 2017), 50, https://eprints.walisongo.ac.id/id/eprint/8222/. 
penelusuran yang dilakukan oleh Riyani terhadap kajian pustaka dan keadaan sosial modern, setidaknya kata hijab memiliki dua konteks yang berbeda pada masa sekarang, yakni hijab sebagai jilbāb atau jubah dan hijab sebagai khimār atau kerudung. ${ }^{40}$

Meski terdapat dalil yang redaksinya memerintahkan perempuan untuk berhijab, hukum berhijab sendiri sampai sekarang masih ada yang memperdebatkan. Seperti yang dikemukakan oleh Quraish Shihab dalam Wawasan Al-Qur'an. Dia mengemukakan pendapat Ibn 'Asyūr bahwa perintah menjulurkan jilbab ke seluruh tubuh pada QS. AlAhzāb: 59 merupakan ajaran yang mempertimbangkan adat orang-orang Arab, sehingga bangsa-bangsa lain yang tidak menggunakan jilbab tidak diberlakukan ketentuan ini. Adapun mengenai redaksi perintah yang terdapat pada ayat-ayat dan hadis-hadis tentang hijab menurutnya boleh jadi bukan merupakan sebuah perintah melainkan anjuran. ${ }^{41}$

Bahkan ada pula cendekiawan muslim yang menganggap bahwa hijab merupakan simbol kemunduran bagi perempuan untuk mendapatkan kesetaraan kedudukan sosial dan perlakuan. ${ }^{42}$ Tidak hanya sebagai simbol kemunduran, hijab pun dianggap sebagai bentuk penindasan dan tirani terhadap perempuan. ${ }^{43}$

Menurut al-Būthī, klaim bahwa hijab merupakan bentuk penindasan dan tirani terhadap perempuan tidak akan muncul jika mereka mengetahui latar belakang disyariatkannya hijab. Menurutnya, perempuan diciptakan dengan segala fitur kecantikan dan pesona feminin yang indah dan ini fitur feminin tersebut sangat menarik bagi lakilaki bahkan dapat membangkitkan hasrat nafsunya. Oleh karenanya, untuk menjaga keutuhan dan keharmonisan hubungan antara laki-laki dan perempuan dalam segala aktivitas kehidupan, maka sangat diperlukan adanya pembatas antara keduanya dan yang berperan sebagai pembatas ini adalah 'hijab.' Inilah makna hijab secara universal yang dipilih oleh al-Būthī. ${ }^{44}$

Adapun universalitas pemaknaan hijab sebagai pembatas antara perempuan dengan laki-laki, lantaran adanya diferensiasi gradasi dalam cakupan makna sensuality expose (mengekspos sensualitas). Seperti mengekspos rambut, menguraikannya dan seterusnya, tidak terkecuali dengan adanya relativitas dalam pemaknaan sensuality influence

\footnotetext{
${ }^{40}$ Riyani, 53.

${ }^{41}$ Shihab, Wawasan Al-Qur'an, 178-79.

${ }^{42}$ Muhamad Hasan Asyadily, "Telaah Kritis Pemahaman Hijab Dalam Framework Fatima Mernissi," FIKRAH 7, no. 2 (31 Desember 2019): 305, https://doi.org/10.21043/fikrah.v7i2.6371.

${ }^{43}$ Di antara tokoh-tokoh yang menentang hijab adalah Qāsim Amīn, Fatimah Mernissi, Zainab Fawwaz, Huda Sya'rawi dan lain sebagainya.

${ }^{44}$ Muhammad Sa'̄̄d Ramadhān al-Būthī, al-Mar'ah bayna Tughyān an-Nizhām al-Gharbiy wa Lathā'if atTasyrī’ ar-Rabbāniy (Beirut: Dār al-Fikr, 1996), 154-55.
} 
(pengaruh sensualitas) di mana boleh jadi seseorang terpengaruh meski hanya sedikit bagian sensualitas yang tersingkap. Pemaknaan hijab semacam ini dimaksudkan untuk menyesuaikan universalitas hukum agar hijab dapat diterapkan pada semua perempuan di segala situasi dan kondisi. ${ }^{45}$

Dalam memahami perintah kewajiban berhijab pada QS. An-Nur: 31, sangat penting untuk memahami potongan ayat wa lā yubdīna zīnatahunna illa mā zahara minhā, sebab pemahaman yang berbeda atas potongan ayat tersebut menghasilkan penafsiran yang berbeda pula. Menurut Ibn Katsīr, potongan ayat tersebut berarti tidak menampakkan sedikit pun dari perhiasan kepada orang asing kecuali sesuatu yang tidak mungkin disembunyikan seperti selendang, sarung dan pakaian, ketiganya tidak menimbulkan fitnah jika ditampakkan. Selain itu, juga bisa diartikan sebagai wajah, kedua telapak tangan, dan cincin. ${ }^{46}$

Kata az-zinnah sendiri pada ayat tersebut menurut Ibn Khalīfah berarti perhiasan yang tersembunyi semisal gelang kaki, pewarna ${ }^{47}$ di kaki, gelang di pergelangan tangan, anting di telinga, dan kalung di leher yang tidak diperbolehkan untuk ditampakkan kepada selain mahram. Larangan memperlihatkan perhiasan tersebut sama halnya dengan larangan memperlihatkan area-area tubuh yang menjadi tempat dikenakannya perhiasan tersebut. ${ }^{48}$

Al-Marāghī menafsirkan illā mā zhahara minhā sebagai apa yang biasa nampak dan tak mungkin dapat disembunyikan seperti cincin, celak mata dan lipstik. Adapun perhiasan seperti gelang tangan, gelang kaki, kalung, mahkota, selempang dan antinganting tidak boleh diperlihatkan sebab semuanya berada di bagian tubuh yang tidak halal untuk dilihat oleh selain mahram yakni bagian hasta, betis, leher, kepala, dada, dan telinga. ${ }^{49}$ Sedangkan Sayyid Quthb menafsirkan illā mà zhahara minhā sebagai perhiasan yang terlihat di wajah dan dua tangan. Kedua perhiasan ini diperbolehkan untuk dilihat oleh selain mahram sekalipun, berdasarkan sabda Rasulullah saw kepada Asma' binti Abu Bakar: "Wahai Asma', sesungguhnya bila wanita telah mencapai usia baligh (haidh), tidak boleh lagi dilihat darinya melainkan ini”. Beliau menunjuk kepada wajah dan dua telapak tangan..$^{50}$

\footnotetext{
45 al-Būthī, 158-59.

${ }^{46}$ Shalah 'Abdul Fattah al-Khalidi, Mudah Tafsir Ibnu Katsir: Shahih, Sistematis, Lengkap, vol. 4 (Jakarta: Maghfirah Pustaka, 2017), 809.

${ }^{47}$ Pewarna semacam henna atau pacar kuku (inai)

${ }^{48}$ Ibn Khalīfah 'Alawiy, Jāmi' An-Nuqūl F̄̃ Asbāb An-Nuzūl wa Syarh Āyātihāa, vol. 1 (t.t.: t.p, 1984), 243.

49 Al-Marāghī, Tafsīr Al-Marāghī, 1946, 18:99.

${ }^{50}$ Sayyid Quthb, F̄̄ Zhilāl Al-Qur'ān, vol. 4 (Mesir: Dār asy-Syurūq, 2003), 2516.
} 
Al-Būthī dalam hal ini sepakat dengan pendapat jumhur ulama bahwa yang dimaksud dengan perhiasan yang biasa tampak adalah 'wajah dan telapak tangan'. Alasan beliau memahaminya demikian karena kedua anggota tubuh itulah yang paling umum dilihat dalam kehidupan bermasyarakat, sehingga tatkala keduanya ikut ditutup maka akan mengganggu aktivitas perempuan. Al-Būthī tidak sepakat dengan pendapat yang mengharuskan wanita menutup semua anggota badan kecuali kedua mata. Menurutnya, pendapat demikianlah yang dapat melemparkan perempuan kepada keterbelakangan di berbagai bidang, dan pandangan hijab yang seperti ini sangat jauh dari ajaran Islam sendiri. Oleh sebab itulah, berbagai keterbelakangan yang terjadi di kalangan perempuan akibat pemahaman semacam ini tidak bisa dijadikan argumen untuk menuduh Islam sebagai penyebabnya, sekaligus bertanggung jawab atasnya. ${ }^{51}$

Selain itu, ketika menafsirkan potongan QS. Al-Ahzāb: 59, “dzālika adnā an yu'rafna falā yu'dzaina", al-Būthī menggarisbawahi bahwa tujuan utama memakai hijab bukan untuk menjadikan penggunanya berakhlak mulia, melainkan untuk menutup pandangan lelaki dari hal-hal yang dapat membangkitkan nafsu birahi, sehingga tidak muncul niat pada dirinya untuk melakukan pelecehan seksual atau perbuatan asusila lainnya sebagai akibat rangsangan tersebut. ${ }^{52}$ Oleh karenanya, sangat wajar jika dari sekian banyak wanita yang berhijab masih ditemukan oknum-oknum yang berperilaku buruk, dan hal ini tidak dapat dijadikan tolok ukur dan alasan untuk memusuhi hijab. Sebab dampak destruktif yang dilahirkan dari eksploitasi sensualitas lebih banyak dibandingkan orang yang berhijab namun berperilaku negatif. ${ }^{53}$

Dengan demikian, tuduhan bahwa hijab adalah belenggu dan penjara bagi perempuan merupakan pemahaman yang salah besar, sebab berhijab bukan berarti mengisolasi perempuan dari masyarakat dan lingkungan, serta menjauhkannya dari aktivitas kehidupan. Model berpakaian juga tidak dapat menjadi tolok ukur apalagi menjadi sebab kemajuan dan kemunduran suatu peradaban. ${ }^{54}$

b. Kepemimpinan Perempuan

Tatkala memperbincangkan persoalan kedudukan perempuan dan boleh tidaknya perempuan menjadi seorang pemimpin, maka QS. An-Nisa: 34 selalu menjadi rujukan

\footnotetext{
51 al-Būthī, al-Mar'ah bayna Tughyān an-Nizhām al-Gharbiy wa Lathā 'if at-Tasyrì̀ ar-Rabbāniy, 165.

52 al-Būthī, 161-62.

53 al-Būthī, 161-62.

${ }^{54}$ al-Būthī, 162-63.
} 
dan argumen dasar terkait persoalan tersebut. Tak jarang ayat tersebut disebut-sebut sebagai bukti bahwa Islam telah mengebiri hak perempuan dan memperlakukan mereka secara tidak adil karena mengkhususkan hak kepemimpinan hanya untuk laki-laki.

Menurut Wadud banyak sekali orang-orang, khususnya para laki-laki, yang menafsirkan ayat tersebut sebagai indikasi tak bersyarat, yakni bahwa laki-laki -secara keseluruhan-diciptakan oleh Tuhan lebih tinggi dari pada perempuan baik dari segi kekuatan fisik maupun akal. Penafsiran semacam ini menurutnya sangat tidak berdasar, sebab tidak ada di dalam Al-Qura'an ayat yang menyatakan superioritas fisik laki-laki atau intelektual mereka. ${ }^{55}$

Menurut al-Būthī, pandangan yang menyatakan bahwa Islam telah bersikap tidak adil dengan menyingkirkan hak perempuan terhadap hal 'kepemimpinan' merupakan pandangan yang terbilang sempit. Bukan berarti kata qawwām dalam ayat tersebut sertamerta menjadi justifikasi eksklusivitas laki-laki atas perempuan. Kata qawwām dalam ayat tersebut secara terminologi berarti segala sesuatu yang menyangkut kepemimpinan dan manajerial. Seperti halnya seseorang yang diserahi tugas untuk memimpin sebuah yayasan, maka dia harus mengatur yayasan tersebut dengan sebaik mungkin. Di sisi lain, menurut al-Būthī, ayat tersebut sebenarnya mendorong agar tidak terjadi kekosongan pemimpin dalam sebuah komunitas. ${ }^{56} \mathrm{Hal}$ ini disabdakan Rasulullah saw, "Jika tiga orang melakukan perjalanan, maka angkatlah salah seorang dari mereka sebagai pemimpin"57. Hadis tersebut memperlihatkan betapa pentingnya peran seorang pemimpin dalam sebuah komunitas, bahkan dalam komunitas safar (perjalanan). Di mana pun dan kapan pun, sosok pemimpin memang sangat penting dalam sebuah komunitas, termasuk komunitas keluarga, sehingga tidak boleh terjadi kekosongan kepemimpinan di dalamnya.

Kemudian, hadis di atas juga memperlihatkan bahwa untuk menjadi pemimpin, seseorang tidak harus menjadi orang yang paling tinggi kedudukannya di sisi Allah. Namun poin yang paling penting adalah kesanggupannya dalam memegang tanggung jawab, menunaikan tugas, serta memiliki kehandalan dalam memimpin dan memanajemen sebuah komunitas. Dengan demikian menurutnya, kepemimpinan

\footnotetext{
55 Amina Wadud, Qur'an and Woman: Rereading the Sacred Text from a Woman's Perspective (New York: Oxford University Press, 1999), 71.

${ }^{56}$ Muhammad Sa'̄̄d Ramadhān al-Būthī, Perempuan Antara Kezaliman Sistem Barat dan Keadilan Islam terj. Darsim dan Imam (Solo: Era Intermedia, 2002), 109.

${ }^{57}$ Bunyi hadisnya, “إذا كان ثلاثة في سفر فليؤمروا أحدهم". Hadis tersebut diriwayatkan oleh Baihaqi, Ahmad, Hakim, dan Daruquthni dari Abu Hurairah.
} 
bukanlah suatu indikator eksklusivitas seseorang, melainkan indikator seseorang yang sanggup menerima tanggung jawab. ${ }^{58}$

Selain itu, klaim bahwa ayat tersebut menjadi justifikasi eksklusivitas laki-laki atas perempuan menjadi sangat tidak relevan. Sebab bertentangan dengan ayat-ayat Al-Qur'an yang menegaskan bahwa laki-laki dan perempuan itu setara secara realitas kemanusiaannya. Ketidaksetaraan keduanya hanya terletak pada seberapa banyak amal mereka di sisi Allah, sebagaimana yang terdapat dalam QS. Ali Imran: 195; An-Nisa: 124; An-Nahl: 97; al-Ahzāb: 35, dan al-Hujurat: $13 .{ }^{59}$

Adapun potongan ayat selanjutnya, "bi mā fadhdhalallāh ba'dhuhum 'ala ba'dh," juga tidak serta merta menjadi bukti superioritas laki-laki atas perempuan. Dalam potongan ayat tersebut terkandung penekanan atas keselarasan antara kemaslahatan dan tugas yang diembankan oleh Allah swt. ${ }^{60}$ Laki-laki dan perempuan memiliki peran dan tanggung jawab yang telah diberikan semenjak awal penciptaan mereka. Peran dan tanggung jawab mereka berbeda satu sama lain sesuai dengan struktur anatomi fisik dan psikis masing-masing mereka.

Dengan struktur anatomi fisik dan psikis yang kuat maka laki-laki dinilai lebih kompeten dan cocok untuk diembankan tugas memimpin, mengatur urusan keluarga dan menjaga kelangsungan hidup mereka dengan memberikan nafkah. Sedangkan perempuan, dengan struktur anatomi fisik dan psikis mereka yang lembut dinilai lebih kompeten dan cocok untuk diembankan tugas merawat, menyusui, dan mendidik anakanak serta menciptakan kebahagiaan di rumah tangga. Tugas dan peran laki-laki ini sama pentingnya dengan tugas dan peran yang diemban oleh perempuan. ${ }^{61}$ Pada hakikatnya tidak ada peran dan tanggung jawab yang dapat menjadikan seseorang lebih tinggi kedudukannya dibandingkan yang lainnya.

Dalam persepsi al-Būthī, Negara wajib koheren dengan hukum Allah berupa adanya prinsip Islam, ${ }^{62}$ dan pada pembahasan terkait kepemimpinan perempuan, al-Būthī memperbolehkan dan tidak melarang kepemimpinan perempuan sebagaimana penjelasan dalam kitabnya terkait hadis Bukhari No. 1423. Menurutnya, hadis tersebut tidak dapat diterima untuk menjadi justifikasi pelarangan pengangkatan perempuan menjadi

\footnotetext{
${ }^{58}$ al-Būthī, Perempuan Antara Kezaliman Sistem Barat dan Keadilan Islam terj. Darsim dan Imam, 110.

59 al-Būthī, 111-12.

${ }^{60}$ al-Būthī, 113-14.

61 al-Būthī, 114.

62 Wahdini, "POLITIK MODERAT," 58.
} 
pemimpin. ${ }^{63}$ Hadis tersebut menurutnya memiliki latar belakang sendiri yang berkenaan dengan peristiwa meninggalnya raja Persia (Kisra) yang dibunuh anaknya, Shirawaih, dan menjadikan dirinya sebagai penguasa. Akan tetapi 6 bulan setelah kematian ayahnya, Shirawaih terbunuh karena minyak wangi beracun yang sengaja ditaruh oleh mendiang ayahnya dalam sebuah lemari setelah tahu bahwa anaknya, Shirawaih, akan membunuhnya. Setelah kematian Shirawaih, diangkatlah anak perempuannya yang bernama Burān bint Shirawaih untuk menduduki singgasana yang ditinggalkan oleh Shirawaih. ${ }^{64}$ Dengan demikian, al-Būthī tidak mempermasalahkan kepemimpinan perempuan -selain menjadi kepala negara tentunya_-dengan dua syarat: 1) Perempuan tersebut harus memiliki kualifikasi yang cukup mumpuni untuk memangku jabatan tersebut, dan 2) Perempuan tersebut tidak melalaikan ketentuan syariat dan etika Islam tatkala memangku jabatan tersebut. ${ }^{65}$

c. Perbedaan Hak Waris 2:1

Persoalan hak waris, di mana perempuan mendapatkan warisan lebih sedikit daripada laki-laki dengan perbandingan $2: 1,{ }^{66}$ juga tak luput dari perhatian pengkaji feminisme. Menurut mereka, hukum waris Islam tidak memihak perempuan. Namun hal ini dibantah oleh al-Būthī dengan argumen bahwa penggalan ayat QS. an-Nisa: 11 tersebut bukanlah kaidah dan ketentuan umum yang harus diaplikasikan ke semua peraturan pembagian warisan yang mempertemukan ahli waris laki-laki dan perempuan. Dengan kata lain, penggalan ayat tersebut hanya berlaku pada kondisi tertentu, yakni pada situasi pembagian warisan yang ahli warisnya adalah suami atau istri dan anak laki-laki serta anak perempuan.

Dalam situasi seperti ini, maka anak laki-laki dan perempuan mendapatkan 'ashabah (sisa) dengan ketentuan anak laki-laki mendapatkan bagian warisan dua kali lebih banyak dibandingkan perempuan. Menurut al-Būthī, pembagian semacam ini dikarenakan beberapa pertimbangan antara lain: 1) Anak laki-laki kelak akan bertanggung jawab dalam menafkahi orang tuanya selain anak-anak dan istrinya sendiri; 2) Anak laki-laki kelak akan memberikan mahar kepada perempuan yang akan ia nikahi; 3) Anak

\footnotetext{
${ }^{63}$ al-Būthī, al-Mar'ah bayna Tughyān an-Nizhām al-Gharbiy wa Lathā 'if at-Tasyrì'’ ar-Rabbāniy, 69.

${ }^{64}$ Nasirudin Al Ahsani, "Kepemimpinan Perempuan Pada Masyarakat Dalam Perspektif Sa'īd Ramadhān AlBūthī (Telaah Hadis Misoginis)," Jurnal Al-Hikmah 18, no. 1 (30 April 2020): 62, https://doi.org/10.35719/alhikmah.v18i1.23.

${ }^{65}$ al-Būthī, al-Mar'ah bayna Tughyān an-Nizhām al-Gharbiy wa Lathā' 'if at-Tasyrì' ar-Rabbāniy, 80.

${ }^{66}$ Adapun ayat Al-Qur'an yang menjadi rujukan dalam pembagian warisan tersebut ialah QS. an-Nisa: $11, l i$ adz-dzakari mitsl hazzi al-untsayayn, Bagian seorang anak laki-laki adalah dua bagian anak perempuan.
} 
perempuan tidak dibebankan kewajiban-kewajiban di atas. Dengan demikian, menurut alBūthī, pembagian warisan yang lebih besar kepada anak laki-laki dibandingkan anak perempuan dinilai sangat adil dan sesuai dengan ketentuan syariat Islam. ${ }^{67}$

d. Poligami

Persoalan lainnya yang tak kalah dikritik dengan keras oleh para feminis adalah kebolehan berpoligami dalam Islam. Menurut kelompok yang kontra poligami berargumen bahwa kalau memang benar Islam memperlakukan laki-laki dan perempuan secara setara, lalu mengapa poliandri tidak diperkenankan untuk perempuan?. Argumentasi semacam ini menurut al-Būthī, lagi-lagi muncul lantaran ketidakpahaman mereka terhadap realitas penciptaan laki-laki dan perempuan. Menurutnya, dalam penciptaan laki-laki dan perempuan terdapat sejumlah perbedaan baik struktur anatomi tubuh (fisik) maupun mental (psikis) mereka. Dari perbedaan yang mendasar tersebut, sangat wajar pula jika kemudian menghasilkan beragam perbedaan lainnya bagi keduanya. Oleh karenanya, perbedaan hukum yang timbul dari perbedaan realitas asal penciptaan tidak dapat dikatakan sebagai diskriminasi, melainkan sebuah konsekuensi logis yang lahir dari beragam perbedaan tadi. ${ }^{68}$ Dengan demikian poligami (poligini) dengan syarat dan ketentuan tertentu-diperbolehkan bagi laki-laki sedangkan poliandri tidak dibenarkan bagi perempuan karena memang hal tersebut adalah lebih sesuai dengan fitrah (kodrat) bagi keduanya. ${ }^{69}$

Selain itu, ada perbedaan persepsi yang mendasar antara Islam dan masyarakat Barat dalam memandang konsep pernikahan. Perbedaan persepsi itulah yang kemudian berimbas kepada perbedaan perlakuan terhadap poligami. Setidaknya menurut al-Būthī ada dua hal yang menyebabkan ketidakpuasan masyarakat Barat terhadap konsep poligami Islam. Pertama, adanya perbedaan persepsi terkait konsep zina antara Islam dan Barat. Dalam Islam, hubungan seksual di luar pernikahan tidak diperbolehkan apapun alasannya. Sedangkan pada masyarakat Barat, hubungan seksual di luar pernikahan tidak dipermasalahkan asalkan hubungan tersebut terjadi atas dasar suka sama suka.

Kedua, terdapat reduksi makna pernikahan pada masyarakat Barat di mana hubungan persahabatan intim antara laki-laki dan perempuan sudah tidak dapat dibedakan dengan

\footnotetext{
${ }^{67}$ al-Būthī, Perempuan Antara Kezaliman Sistem Barat dan Keadilan Islam terj. Darsim dan Imam, 123-24.

68 al-Būthī, 138-39.

${ }^{69}$ M. Quraish Shihab, Perempuan: dari Cinta sampai Seks; dari Nikah Mut'ah sampai Nikah Sunnah; dari Bias Lama sampai Bias Baru (Tanggerang: Lentera Hati, 2018), 200-201.
} 
hubungan pernikahan, bahkan dapat dikatakan telah menggantikan pernikahan itu sendiri. $^{70}$ Dengan demikian, wajar -meskipun ironis-apabila pelacuran dan perselingkuhan pada masyarakat Barat dianggap sebagai hal yang lumrah sedangkan poligami dipandang negatif. Berbeda dengan Islam yang memandang positif poligami sebab merupakan pernikahan sah serta mengharamkan pelacuran dan perselingkuhan yang melanggar maqāshid asy-syarī'ah: hifdz an-nasl yakni menjaga keturunan.

\section{Konsep Kesetaraan dan Perbedaan Laki-laki dan Perempuan}

Dalam salah satu subbab kitabnya, al-Būthī secara gamblang menjelaskan perbedaan kesetaraan yang dipahami Islam dan yang dipahami oleh masyarakat Barat. Menurutnya, kesetaraan antara laki-laki dan perempuan yang dipahami Islam adalah kesetaraan yang terletak pada realitas kemanusiaan mereka dalam mengemban kewajiban dan menerima hak. Pada waktu yang sama, dalam kesetaraan itu juga terdapat perbedaan berupa perbedaan kemampuan, bakat, keahlian, dan karakteristik masing-masing. Dengan demikian, laki-laki dan perempuan sama-sama setara dalam hal realitas kemanusiaan di mana mereka sama-sama memiliki hak dan juga kewajiban yang harus ditunaikan. Namun, dalam kesetaraan dan persamaan itu, keduanya juga memiliki perbedaan antara satu sama lain berupa kemampuan, bakat, keahlian, dan karakteristik yang merupakan pemberian dan kebijakan dari Allah swt, sehingga perbedaan tersebut merupakan hal yang tak dapat dihindarkan. ${ }^{71}$

Hal ini berbeda dengan konsep kesetaraan yang ditawarkan oleh Barat. Kesetaraan yang dianut oleh masyarakat dan para feminis Barat adalah kesetaraan yang menempatkan laki-laki dan perempuan pada acuan-acuan sosial yang sama sehingga mereka harus mengikuti kerangka acuan sosial yang sama pula, tinggal di tempat dan aturan yang sama, struktur anatomi fisik dan psikis mereka juga dianggap sama sehingga mereka dibebani kewajiban dan memiliki hak yang sama pula. Laki-laki dan perempuan harus menikmati hak-hak mereka tanpa adanya pembedaan jender. ${ }^{72}$ Hal ini tentunya sangat merugikan perempuan karena secara kodrat, baik fisik maupun psikis, perempuan sangat berbeda dengan laki-laki, sehingga jika kewajiban yang harus ditunaikan oleh perempuan sama dengan laki-laki, sedangkan secara fisik laki-laki lebih kuat daripada perempuan, tentu hal tersebut melawan fitrah (kodrat) yang diberikan oleh Tuhan.

\footnotetext{
${ }^{70}$ Al-Būthī, Perempuan Antara Kezaliman Sistem Barat dan Keadilan Islam terj. Darsim dan Imam, 143-44.

${ }^{71}$ al-Būthī, Perempuan Antara Kezaliman Sistem Barat dan Keadilan Islam terj. Darsim dan Imam, 106.

72 al-Būthī, 103-4.
} 


\section{Penutup}

Berdasarkan analisis dari data-data kajian pustaka sebelumnya, penelitian ini menyimpulkan bahwa Sa’̄̄d Ramadhān al-Būthī menolak seluruh klaim dan tuduhan para feminis bahwa Islam telah memarjinalkan kedudukan perempuan melalui empat ajaran Islam yakni hijab, kepemimpinan perempuan, hak warisan perempuan, dan poligami.

Mengenai persoalan hijab, meskipun ada beberapa cendekiawan muslim yang memperdebatkan kewajiban mengenakannya, al-Būthī berpegang teguh dengan pendapat mayoritas ulama bahwa mengenakannya adalah wajib dan area yang harus ditutup adalah seluruh anggota badan kecuali wajah dan telapak tangan. Al-Būthī membantah tuduhan bahwa hijab adalah simbol kemunduran karena maju dan mundurnya peradaban suatu negeri tidak ada hubungannya dengan cara berpakaian penduduknya.

Adapun mengenai QS. An-Nisa: 34 sebagai justifikasi superioritas laki-laki atas perempuan sama sekali tidak relevan. Jabatan kepemimpinan bukanlah indikator eksklusivitas dan superioritas, melainkan indikator kesanggupan menerima tanggung jawab. Al-Būthī tidak mempermasalahkan kepemimpinan perempuan selama bukan menjadi kepala negara dengan mensyaratkan dua hal, 1) Berkualifikasi, dan 2) Tidak melalaikan ketentuan syariat dan etika Islam.

Sedangkan dalam hal pembagian harta warisan, al-Būthī meluruskan kesalahpahaman penggalan QS. an-Nisa': 11 di mana ayat tersebut bukanlah kaidah dan ketentuan umum yang harus diaplikasikan ke semua peraturan pembagian warisan yang mempertemukan ahli waris laki-laki dan perempuan. Dengan kata lain, penggalan ayat tersebut hanya berlaku pada kondisi tertentu, yakni pada situasi pembagian warisan yang ahli warisnya adalah suami atau istri dan anak laki-laki serta anak perempuan. Adapun dalam persoalan poligami, menurut al-Būthī hal ini lebih dikarenakan adanya perbedaan persepsi yang mendasar antara Islam dan Barat dalam memandang esensi dan konsep pernikahan dan zina.

\section{E. Daftar Pustaka}

Abidin, Zainal. "Kesetaraan Gender dan Emansipasi Perempuan dalam Pendidikan Islam." Tarbawiyah Jurnal Ilmiah Pendidikan 12, no. 01 (2017): 1-17.

Adaruddin, Sahrani. "Feminisme Perspektif Islam." Al-Wardah: Jurnal Kajian Perempuan, Gender dan Agama 14, no. 2 (2020): 245-53. https://doi.org/10.46339. 
Adinugraha, Hendri Hermawan, Asep Suraya Maulana, dan Mila Sartika. "Kewenangan dan Kedudukan Perempuan dalam Perspektif Gender: Suatu Analisis Tinjauan Historis." Marwah: Jurnal Perempuan, Agama dan Jender 17, no. 1 (2018): 42-62.

Ahsani, Nasirudin Al. "Kepemimpinan Perempuan Pada Masyarakat Dalam Perspektif Sa ${ }^{1} \mathrm{id}$ Ramaḍān Al-Būṭ̂̄ (Telaah Hadis Misoginis).” Jurnal Al-Hikmah 18, no. 1 (30 April 2020): 57-74. https://doi.org/10.35719/alhikmah.v18i1.23.

Al-Așfahān̄̄, Ar-Raghīb. Al-Mufradāt fì Gharīb al-Qur'ān. Vol. 1. t.t.: Maktabah Nizar Mushthafa al-Baz, t.th.

'Alawiy, Ibn Khalīfah. Jāmi' An-Nuqūl Fì Asbāb An-Nuzūl wa Syarh Ayātihāa. Vol. 1. t.t.: t.p, 1984.

Al-Būth̄̄, Muhammad Sa'̄̄d Ramadhān. Perempuan Antara Kezaliman Sistem Barat dan Keadilan Islam terj. Darsim dan Imam. Solo: Era Intermedia, 2002.

Al-Marāghī, Ahmad Mushthafa. Tafsīr Al-Marāghī. Vol. 18. Mesir: Mushthafā al-Bābī alHalbī, 1946.

—. Tafsìr Al-Marāghī. Vol. 22. Mesir: Mushthafā al-Bābī al-Halbī, 1946.

Anggraeni, D., Hakam, A., Mardhiah, I., \& Lubis, Z. (2019). Membangun Peradaban Bangsa Melalui Religiusitas Berbasis Budaya Lokal. Jurnal Studi Al-Qur'an, 15(1), 95-116.

Amin, Muhammad. "Feminisme pada Modernisasi di Jepang Nihon De No Kindaika Ni Taisuru Feminizumu." Skripsi, Universitas Sumatera Utara, 2018.

Arif, Zahra Zaini. "Peran Ganda Perempuan dalam Keluarga Pespektif Feminis Muslim Indonesia." Indonesian Journal of Islamic Law 1, no. 2 (2019): 97-126.

Ashriyanti, Nabila, dan Nasirudin Al Ahsani. "Kepemimpinan Perempuan Dalam Masyarakat Dalam Perspektif Sa '̄id Ramaḍān Al-Būṭi: Telaah Hadis Misoginis.” Al-Hikmah 18, no. 1 (2019): 57-74.

Asyadily, Muhamad Hasan. "Telaah Kritis Pemahaman Hijab Dalam Framework Fatima Mernissi.” FIKRAH 7, no. 2 (31 Desember 2019): 303-32. https://doi.org/10.21043/fikrah.v7i2.6371.

Baharjo, Mudjia. Dasar-Dasar Hemeneutiks Antara Intensionalisme \& Gadamerian. Yogyakarta: AR-RUZZ MEDIA, 2008.

Būthī, Muhammad Sa'īd Ramadhān al-. al-Mar'ah bayna Tughyān an-Nizhām al-Gharbiy wa Lathā 'if at-Tasyrī' ar-Rabbāniy. Beirut: Dār al-Fikr, 1996.

. Perempuan Antara Kezaliman Sistem Barat dan Keadilan Islam terj. Darsim dan Imam. Solo: Era Intermedia, 2002. 
Djaelani, Aunu Rofiq. "Teknik Pengumpulan Data dalam Penelitian Kualitatif." PAWIYATAN 20, no. 1 (2013).

Fadhil, A. (2018). Nilai-Nilai Spritualitas dan Harmoni Beragama dalam Wirid Harian Kitab Al-Aurad Al-Nur'aniyyah. Hayula: Indonesian Journal of Multidisciplinary Islamic Studies, 2(2), 129-144.

Hakam, A., Anggraeni, D., \& Fadhil, A. (2020). Pola dan Narasi Gerakan Keislaman di Universitas Negeri Jakarta. Hayula: Indonesian Journal of Multidisciplinary Islamic Studies, 4(2), 263-278.

Handayani, Tri. "Reafirmasi Posisi Perempuan Mengulas Pandangan Lama." Jurnal AlDirayah 4, no. 1 (2018): 40-50.

Humairah, M. I., \& Fadhil, A. (2019). Gerakan Intifadhah dan Kemunculan Hamas (19871993). PERIODE: Jurnal Sejarah dan Pendidikan Sejarah, 1(1), 1-14.

Khalidi, Shalah 'Abdul Fattah al-. Mudah Tafsir Ibnu Katsir: Shahih, Sistematis, Lengkap. Vol. 4. Jakarta: Maghfirah Pustaka, 2017.

Kontestasi, Diskursus, Agama Dan, Muhammad Soleh Aminullah, Studi Pemikiran, Muhammad Sa, Muhammad Wahdini, dan Al Makin. "POLITIK MODERAT Studi Pemikiran Muhammad Sa'id Ramadhan Al-Buthi." Sosiologi Agama: Jurnal Ilmiah Sosiologi Agama dan Perubahan Sosial 14, no. 1 (2020).

Magdalena, R. "Kedudukan Perempuan dalam Perjalanan Sejarah (Studi Tentang Kedudukan Perempuan dalam Masyarakat Islam)." Harakat an-Nisa: Jurnal Studi Gender dan Anak II, no. 1 (2017). http://e-journal.lp2m.uinjambi.ac.id/ojp/index.php/anNisa/article/download/116/52/.

Mufid, Muhammad. Belajar dari : Tiga Ulama Syam Fenomenal dan Inspiratif. Jakarta: PT Elex Media Komputindo, 2015.

Mukit, Abdul. "Pendidikan Akidah: Telaah Pemikiran Muhammad Said Ramdlan al-Buthi." Tawazun: Jurnal Pendidikan Islam 8, no. 1 (30 Januari 2015): 1-26. https://doi.org/10.32832/tawazun.v8i1.1130.

Munfarida, Elya. “Perempuan dalam Tafsir Fatima Mernisi.” Maghza 1, no. 2 (2016).

Narulita, S., Aulia, R. N., Nugrahaeni, E., Wajdi, F., Mardhiah, I., \& Hadiyanto, A. (2019, August). Religion Learning Strategies for the Z Generation. In 1st International Conference on Education Social Sciences and Humanities (ICESSHum 2019) (pp. 870-875). Atlantis Press. 
Permana, Sugiri. "Kesetaraan Gender Dalam Ijtihad Hukum Waris Di Indonesia.” AsySyari'ah 20, no. 2 (2018): 117-32. https://doi.org/10.15575/as.v20i2.3210.

Putri, Dwi Amanda. "PERAN PEREMPUAN DALAM KELUARGA KOREA PADA MASA DINASTI JOSEON (1392 - 1910) BERDASARKAN AJARAN KONFUSIANISME.” Diploma, UNIVERSITAS NASIONAL, 2019. http://repository.unas.ac.id/1806/.

Quthb, Sayyid. F̄̄ Zhilāl Al-Qur'ān. Vol. 4. Mesir: Dār asy-Syurūq, 2003.

Riyani, R. "Makna Hijab dalam Al-Qur'an : Studi Tematik Ayat-ayat Hijab.” Skripsi, UIN Walisongo, 2017. https://eprints.walisongo.ac.id/id/eprint/8222/.

Shābūnī, Muhammad 'Alī ash-. Shafwat at-Tafāsīr. Vol. 2. Lebanon: Dār al-Fikr, 2001.

Shihab, M. Quraish. Perempuan: dari Cinta sampai Seks; dari Nikah Mut'ah sampai Nikah Sunnah; dari Bias Lama sampai Bias Baru. Tanggerang: Lentera Hati, 2018.

-. Wawasan Al-Qur'an: Tafsir Maudhu'i atas Pelbagai Persoalan Umat. Bandung: Mizan, 1996.

Sugiyono. Metode Penelitian Kuantitatif, Kualitatif dan R\&D. Bandung: Alfabeta, 2016.

Suyūṭ̣̂, Jalāl ad-Dīn as-. Lubāb an-Nuqūl fì Asbāb an-Nuzūl. Beirut: Mu`assasah al-Kutub aś-Sंaqāfiyyah, 2002.

Wadud, Amina. Qur'an and Woman: Rereading the Sacred Text from a Woman's Perspective. New York: Oxford University Press, 1999.

\section{Situs Internet}

https://liputanislam.com/kajian-islam/mengenang-syaikh-muhammad-said-ramadhan-albuthy/ Diakses pada tanggal 19 April 2020.

https://islami.co/said-ramadhan-al-buthi-ulama-yang-menjadi-musuh-gerakan-oposisi/ diakses pada tanggal 19 April 2020. 